\title{
Faktor Risiko yang Berhubungan dengan Kejadian Stunting di Indonesia: Studi Literatur
}

\author{
Risk Factors Related to Stunting in Indonesia: Literature Study \\ Moch. Irfan Hadi ${ }^{*}$, Mei Lina Fitri Kumalasari ${ }^{1}$, Estri Kusumawati ${ }^{1}$ \\ 1) Fakultas Psikologi dan Kesehatan, UIN Sunan Ampel Surabaya, Indonesia \\ min_huinsby...ac.id \\ DOI: http://doi.org/10.29080/jhsp.v3i2.238
}

Received: September 2019, Accepted: September 2019, Published : September 2019

\begin{tabular}{l}
\hline Kata Kunci \\
\hline faktor risiko, \\
stunting, \\
Indonesia \\
\hline
\end{tabular}

\begin{abstract}
Abstrak
Stunting adalah suatu keadaan dimana indeks tinggi badan menurut umur di bawah -2 SD berdasarkan dari standar WHO. Keadaan ini adalah manifestasi jangka panjang dari faktor konsumsi diet berkualitas yang rendah, penyakit infeksi yang terjadi berulang dan faktor lingkungan. Tujuan penelitian ini adalah untuk mengetahui faktor-faktor yang berhubungan dengan kejadian stunting. Hasil penelitian menunjukkan bahwa stunting dipengaruhi oleh tingkat asupan energi, riwayat durasi penyakit infeksi, berat badan lahir, tingkat pendidikan ibu dan tingkat pendapatan keluarga.

Metode penelitian ini adalah studi literatur dengan berbagai referensi, yaitu artikel atau jurnal penelitian, review jurnal, annual report, buku dan data-data yang mendukung dengan kejadian stunting yang diterbitkan dari tahun 2009 - 2019. Pencarian dilakukan menggunakan mesin pencari google di internet dengan kata kunci yang terkait, seperti: stunting, faktor resiko, penyakit infeksi, imunisasi dan vaksin. Pencarian database dilakukan di PubMed, PLoS, ResearchGate, WHO dan Depkes RI.

Kesimpulan dari penelitian ini adalah memberi saran kepada pemerintah, instansi kesehatan, dan pihak terkait untuk berkolaborasi menerapkan kebijakan untuk mengurangi risiko stunting. Selain itu, masyarakat disarankan mendapatkan pendidikan yang berkualitas, memberikan asupan nutrisi yang seimbang serta meningkatkan derajat kesehatan anak dan pengembangan EST (Eco Support Theory) dalam rangka mengurangi stunting di Indonesia.

Abstract

Stunting is a state of height index according to age below minus two standard deviations based on WHO standards. Stunting is a long-term manifestation of low-quality diet consumption factor, recurrent infectious disease, and environment. The purpose of this research is to know the factors related to the stunting event. The results showed that stunting influenced by the level of energy intake, history of infection duration, birth weight, maternal education level and family income level.

This research method is the study of literature with various references such as articles or research journals, review journals, annual report, a textbook on stunting published from 2009-2019.

Search is done with the Google search engine on the Internet with related keywords, such as stunting, risk factors, infectious diseases, immunizations, vaccine databases published then sought by using the term - These terms, including PubMed, PLoS, ResearchGate, WHO and Depkes RI.

The conclusion of the study was to advise governments, health agencies, and related parties to collaborate on implementing policies to reduce the risk of stunting. Besides, the community is advised to obtain a quality education, provide balanced nutrient intake and increase the degree of child health and development of EST (Eco Support Theory) to eliminate stunting in Indonesia.
\end{abstract}

\section{Keywords}

Risk factors,

Stunting,

Indonesia

\section{PENDAHULUAN}

Indonesia menduduki peringkat prevalensi stunting kelima di dunia (1). Hasil penelitian dari Riset Kesehatan Dasar (Riskesdas) pada tahun 2013 menunjukkan bahwa prevalensi stunting secara nasional 
adalah 37,2\%. Hal ini termasuk masalah kesehatan masyarakat yang berat karena berada dalam rentang 30 $39 \%$ (2). Stunting terjadi karena adanya defisiensi nutrisi yang terjadi selama seribu pertama kehidupan. Keadaaan ini akan menimbulkan gangguan perkembangan fisik anak yang irreversible, sehingga menyebabkan penurunan kemampuan kognitif dan motorik serta penurunan performa kerja. Anak yang menderita stunting memiliki rerata skor Intelligence Quotient (IQ) sebelas poin lebih rendah dibandingkan rerata skor IQ pada anak normal. Intervensi kepada anak yang mengalami gangguan tumbuh kembang karena kekurangan gizi akan berlanjut hingga dewasa apabila tidak dilakukan sejak dini $(3,4)$.

Berdasarkan Sulastri (2012) dan Trihono (2015), bahwa anak yang mengalami stunting akan mengalami penurunan prestasi sekolah, tingkat pendidikan rendah dan pendapatan yang rendah ketika dewasa. Selain itu, anak yang mengalami stunting memiliki kemungkinan lebih besar tumbuh menjadi individu dewasa yang tidak sehat. Stunting pada anak juga berhubungan dengan peningkatan kerentanan anak terhadap penyakit, baik penyakit menular maupun penyakit tidak menular (PTM) serta peningkatan risiko overweight dan obesitas. Kasus stunting pada anak dapat dijadikan prediktor rendahnya kualitas sumber daya manusia suatu negara. Hal ini disebabkan karena stunting dapat menurunkan kemampuan kognitif, menurunkan produktivitas dan meningkatkan risiko penyakit sehingga akan mengakibatkan kerugian jangka panjang untuk perekonomian Indonesia $(4,5)$. Penelitian ini bertujuan untuk mengetahui faktor-faktor yang berhubungan dengan kejadian stunting.

\section{Metode Penelitian}

\section{Strategi pencarian}

Penelitian ini merupakan studi literatur yang mencari database dari berbagai referensi, seperti jurnal penelitian, review jurnal, annual report, buku dan data-data yang berkaitan dengan stunting, faktor risiko, penyakit infeksi, imunisasi dan vaksin yang diterbitkan pada tahun 2009-2019. Pencarian literatur dilakukan dengan menggunakan mesin pencari google di internet dengan kata kunci : stunting, faktor resiko, penyakit infeksi, imunisasi, vaksin. Database yang diambil dari artikel yang dipublikasikan pada PubMed, PLoS, Researchgate, WHO dan Depkes RI.

\section{Kriteria seleksi data}

Bahan yang dicari diseleksi dengan menggunakan kriteria inklusi. Kriteria inklusi yang digunakan adalah faktor resiko yang berhubungan dengan stunting. Sumber yang digunakan hanya terfokus pada faktor resiko yang berhubungan dengan stunting. Sedangkan untuk kriteria eksklusi yaitu jurnal - jurnal yang diterbitkan di bawah tahun 2009.

\section{Hasil Penelitian}

Dari studi literatur didapatkan hasil sebagai berikut :

Tabel 1. Hasil Studi Literatur

\begin{tabular}{lll}
\hline No & \multicolumn{1}{c}{ Faktor Resiko Stunting } & \multicolumn{1}{c}{ Literatur } \\
\hline 1. & Hubungan Karakteristik Keluarga dengan Kejadian Stunting : & Pipes LP. 1985; Aries M,dkk. 2012; Rahayu A, \\
& Faktor pendidikan ibu, tingkat pengetahuan ibu tentang gizi, & Khairiyati L. 2014;Ekawaty M,dkk. 2015; \\
& pendapatan keluarga, jumlah anggota rumah tangga & Huang W. 2015; Rahmad AHAL, Miko A. 2016; \\
& & Cruz LMG,dkk. 2017; SILVA, Diana. 2017;; \\
& & Safitri CA, Nindya TS. 2017; Sanin KI,dkk. 2018; \\
& & Lisanu M, Andargie BG. 2018
\end{tabular}


2. Hubungan Penyakit Infeksi, Berat Badan Lahir, Pemberian ASI, Imunisasi Dasar Pada Kejadian Stunting : rerata durasi sakit saat balita > 3 hari per episode sakit, frekuensi penyakit infeksi, Berat Badan Lahir Rendah (BBLR), Status pemberian ASI eksklusif, Imunisasi dasar

3. Hubungan Karakteristik Gizi dengan Kejadian Stunting : tingkat kecukupan asupan energi, tingkat asupan protein
Dekker LH,dkk.2010; Weisz A, dkk.2011; Welasasih BD, Wirjatmadi RB. 2012; NorrisSA. 2014; Gaayeb L, dkk2014; Efendhi A. 2015; Rahayu A,dkk 2015; Bentian I, 2015;Danaei G, dkk 2016; Berendsen MLT, dkk. 2016; Apoina K,dkk 2016; Cruz LMG, dkk 2017; Hindrawati N, Rusdiarti. 2018; Lestari E, Hasanah F, Nugroho N. 2018; Kementerian Kesehatan RI. 2018; Vonaesch P. 2018

Barilla Center for Food and Nutrition. 2009; Sulastri D.; 2012; Fatemeh E, Roshanak. 2013; Aridiyah FO,dkk. 2015;Damayanti RA,dkk.2016;. Saaka M, Galaa SZ. 2016; Schoenbuchner SM,dkk. 2019

\section{Pembahasan}

\section{Stunting dan Gambaran Kejadian Stunting}

Stunting merupakan suatu keadaan malnutrisi yang berhubungan dengan pemenuhan zat gizi yang kurang pada masa lalu sehingga termasuk dalam masalah gizi yang bersifat kronis. Stunting diukur sebagai status gizi dengan memperhatikan tinggi atau panjang badan, umur, dan jenis kelamin balita. Kebiasaan tidak mengukur tinggi atau panjang badan balita di masyarakat menyebabkan kejadian stunting sulit disadari sehingga menjadi salah satu fokus pada target perbaikan gizi di dunia sampai tahun 2025. Stunting atau perawakan pendek (shortness) adalah suatu keadaan tinggi badan (TB) seseorang yang tidak sesuai dengan umur, yang penentuannya dilakukan dengan menghitung skor Z-indeks tinggi badan menurut umur (TB/U). Seseorang dikatakan stunting bila skor Z-indeks TB/U-nya dibawah-2 SD (standar deviasi).

Prevalensi stunting di Indonesia menurut data Riskesdas tahun 2013 adalah sebesar 37,2\%. Hal ini lebih tinggi apabila dibandingkan dengan prosentase stunting secara globlal menurut UNICEF, yaitu sebesar 22,9\% (1,2). Sedangkan, hasil dari Riskesdas tahun 2018 menunjukkan status gizi di Indonesia sudah mengalami perbaikan. Proporsi stunting atau balita pendek karena kurang gizi kronik turun dari 37,2\% pada tahun 2013 menjadi 30,8\% pada riskesdas 2018. Meski demikian, angkanya masih jauh dari target WHO, yaitu 20\%. Jika dibandingkan dengan negara lain seperti Ethiopia sebesar $39.3 \%$; Nepal $42.7 \%$ s.d 51 \%; Eropa 0.9 s.d 6.2 \%; Afrika 34 \%; Asia Selatan 35 \%; Oceania 38 \%, Prevalensi Stunting di Indonesia masih rendah (6-11).

\section{Faktor Resiko Yang Berhubungan dengan Stunting}

Berdasarkan hasil studi literatur yang dilakukan bahwa terdapat beberapa faktor resiko yang memiliki pengaruh dan tidak berpengaruh pada kejadian stunting, faktor resiko tersebut adalah

\section{Hubungan Karakteristik Keluarga dengan Kejadian Stunting}

Berdasarkan hasil studi literatur, didapatkan hasil yaitu ada hubungan yang bermakna antara tingkat pendidikan ibu dengan kejadian stunting (12). Selain itu, Berdasarkan analisis multivariat bahwa faktor pendidikan ibu merupakan faktor yang memiliki hubungan paling dominan dengan kejadian stunting pada anak (13-15).

Selain itu, faktor resiko yang berhubungan dengan stunting adalah tidak terdapat hubungan yang signifikan antara tingkat pengetahuan ibu tentang gizi dengan kejadian stunting (16). Hal ini disebabkan oleh tumbuh kembang anak dipengaruhi oleh faktor-faktor keluarga lainnya, seperti: pekerjaan/ pendapatan keluarga, pendidikan orang tua, stabilitas rumah tangga, dan kepribadian orang tua (17-19).

Berdasarkan hasil studi literatur bahwa pendapatan keluarga merupakan salah satu faktor yang 
memiliki hubungan bermakna dengan kejadian stunting pada balita (20). Orang tua dengan pendapatan keluarga yang memadai akan memiliki kemampuan untuk menyediakan semua kebutuhan primer dan sekunder anak. Keluarga dengan status ekonomi yang baik juga memiliki akses pelayanan kesehatan yang lebih baik (21). Anak pada keluarga dengan status ekonomi rendah cenderung mengkonsumsi makanan dalam segi kuantitas, kualitas, serta variasi yang kurang. Status ekonomi yang tinggi membuat seseorang memilih dan membeli makanan yang bergizi dan bervariasi (22). Selain itu, berdasarkan studi literatur bahwa antara jumlah anggota rumah tangga dengan kejadian stunting tidak memiliki hubungan yang signifikan. Hal ini didasarkan pada penelitian yang dilakukan di wilayah kerja Puskesmas Kedung banteng Banyumas, jumlah anggota keluarga tidak memiliki hubungan yang signifikan dengan kejadian stunting pada anak batita (23-27).

\section{Hubungan Penyakit Infeksi, Berat Badan Lahir, Pemberian ASI, Imunisasi Dasar Pada Kejadian Stunting}

Berdasarkan studi literatur ditemukan bahwa rerata durasi sakit saat balita $>3$ hari per episode sakit memiliki hubungan yang bermakna dengan kejadian stunting pada anak SD (28). Selain itu, peningkatan durasi diare dan ISPA berhubungan dengan penurunan status gizi anak, penurunan indeks $\mathrm{BB} / \mathrm{U}$ dan $\mathrm{TB} / \mathrm{U}$, hambatan pertumbuhan. Ini disebabkan diare berhubungan dengan gangguan absorpsi nutrien selama dan setelah episode diare. Selain itu, hambatan pertumbuhan yang disebabkan oleh ISPA berhubungan dengan peningkatan kebutuhan metabolik dan gangguan intake makanan selama periode penyakit (29).

Berdasarkan studi literatur bahwa frekuensi penyakit infeksi (ISPA dan diare) tidak memiliki hubungan yang signifikan dengan kejadian stunting pada anak usia 12-48 bulan (30). Hal ini disebabkan stunting tidak hanya dipengaruhi oleh frekuensi penyakit infeksi, tetapi juga dipengaruhi oleh durasi penyakit infeksi dan asupan nutrien selama episode penyakit infeksi tersebut. Hasil penelitian diatas juga memiliki kesamaan dengan hasil penelitian yang dilakukan di pada negara-negara berkembang dan negara maju, penyakit infeksi memiliki peran yang cukup penting terhadap kejadian stunting (27,31-33).

Berat badan lahir memiliki hubungan yang bermakna dengan kejadian stunting. Berdasarkan studi literatur, bahwa faktor Berat Badan Lahir Rendah (BBLR) merupakan faktor risiko yang paling dominan terhadap kejadian stunting pada anak balita (34). Karakteristik bayi saat lahir (BBLR atau BBL normal) merupakan hal yang menentukan pertumbuhan anak, anak dengan riwayat BBLR mengalami pertumbuhan linear yang lebih lambat dibandingkan Anak dengan riwayat BBL normal (35). Periode kehamilan hingga dua tahun pertama usia anak merupakan periode kritis. Gangguan pertumbuhan pada periode ini sulit diperbaiki dan anak sulit mencapai tumbuh kembang optimal (18,25,36-38). Status pemberian ASI eksklusif tidak terdapat hubungan yang signifikan dengan kejadian stunting (39). Hal ini disebabkan oleh keadaan stunting tidak hanya ditentukan oleh faktor status pemberian ASI eksklusif, tetapi juga dipengaruhi oleh faktor lain seperti: kualitas Makanan Pendamping ASI (MP-ASI), kecukupan asupan gizi yang diberikan kepada anak setiap hari, serta status kesehatan bayi (40-42).

Imunisasi dasar merupakan program yang rutin yang bertujuan untuk melindungi anak dari penyakit yang akan menginfeksi. Berdasarkan studi literatur, tidak terdapat hubungan yang signifikan antara status imunisasi dasar dengan kejadian stunting. Ini didasarkan hasil penelitian yang dilakukan di wilayah kerja Puskesmas Siloam Tamako, Kabupaten Kepulauan Sangihe, Provinsi Sulawesi Utara bahwa tidak adanya hubungan yang signifikan antara status imunisasi dasar dengan kejadian stunting pada pada 
anak TK (43-46). Ini disebabkan bahan yang digunakan untuk imunisasi dasar telah melalui uji klinik sehingga tidak menyebabkan stunting.

\section{Hubungan Karakteristik Gizi dengan Kejadian Stunting}

Masa awal anak-anak ditandai dengan pertumbuhan yang cepat (growth spurt). Mencukupi kebutuhan asupan energi yang adekuat merupakan hal yang sangat penting bagi anak. Energi tersebut bersumber dari makronutrien seperti: karbohidrat, lemak, dan protein $(48,49)$. Berdasarkan hasil penelitian yang dilakukan di Kelurahan Kejawan Putih Tambak, Kecamatan Mulyorejo, Kota Surabaya, yaitu terdapat perbedaan tingkat kecukupan asupan energi yang signifikan antara balita stunting dan non stunting (47). Selain itu, Hasil penelitian yang dilakukan di Kelurahan Bandar Buat, Kecamatan Lubuk Kilangan, Kota Padang, yaitu tidak terdapat hubungan yang signifikan antara tingkat asupan protein dengan kejadian stunting pada siswa kelas I sekolah dasar $(5,24,50,51)$. Ini disebabkan tingkat asupan protein dipengaruhi oleh kemampuan metabolik masing-masing hospes, membutuhkan kajian lebih lanjut tentang pengaruh diversitas genetik terhadap asupan protein.

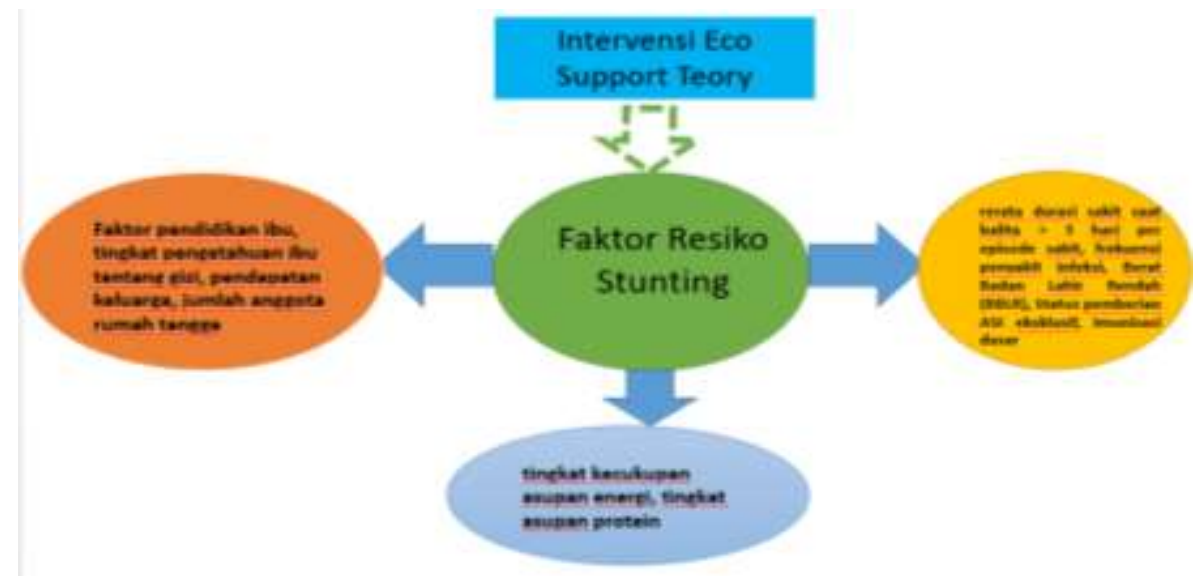

Gambar 1. Faktor resiko stunting dan road map penelitian

\section{KESIMPULAN}

Terdapat hubungan yang bermakna antara tingkat asupan energi, rerata durasi sakit, berat badan lahir, tingkat pendidikan ibu, dan tingkat pendapatan keluarga dengan kejadian stunting. Faktor tingkat pendidikan ibu memiliki hubungan paling dominan. Tingkat asupan protein, rerata frekuensi sakit, status pemberian ASI eksklusif, status kelengkapan imunisasi dasar, tingkat pengetahuan ibu tentang gizi, dan jumlah anggota rumah tangga tidak menunjukkan hubungan yang signifikan dengan kejadian stunting. Disarankan mendapatkan pendidikan yang berkualitas, memberikan asupan nutrien yang seimbang dan meningkatkan derajat kesehatan anak. Saran untuk penelitian selanjutnya adalah Pengembangan EST (Eco Support Teori) dalam rangka mengeliminasi Stunting di Indonesia.

\section{Daftar Pustaka}

1. Tim Nasional Percepatan Penanggulangan Kemiskinan (TNPPK). 100 kabupaten/ kota prioritas untuk intervensi anak kerdil (stunting). Jakarta: TNPPK; 2017.

2. Kemenkes RI. Riset kesehatan dasar (Riskesdas) [Internet]. 2013. Available from: http://www.depkes.go.id/resources/download/infoterkini/materi_rakorpop_2018/Hasi1\%20Riskesdas\%202 018.pdf 
3. Kementerian Kesehatan RI. Peraturan menteri kesehatan republik indonesia nomor 39 tahun 2016 tentang pedoman penyelenggaran program Indonesia sehat. Keementerian Kesehatan RI; 2016.

4. Trihono A, DH T, A I, NH U, T T. Pendek (stunting) di Indonesia, masalah dan solusinya. Jakarta: Lembaga Penerbit Balitbangkes; 2015.

5. Sulastri D. Faktor determinan kejadian stunting pada anak usia sekolah di Kecamatan Lubuk Kilangan Kota Padang. Padang: Majalah Kedokteran Andalas; 2012.

6. Astuti I. diakses 22 agustus [Internet]. Riset Kesehatan Nasional 2018: Angka Stunting Turun. 2019. Available from: https://mediaindonesia.com/read/detail/195157-riset-kesehatan-nasional-2018-angkastunting-turun

7. Kemenkes RI. diakses 22 agustus [Internet]. 2019. Available from: http://www.depkes.go.id/resources/download/infoterkini/materi_rakorpop_2018/Hasil\%20Riskesdas\%202 018.pdf

8. Berhanu G, Solomon M, Mekonnen S. Prevalence of stunting and associatedfactors among preschool children: Acommunity based comparative crosssectional study in Ethiopia. BMC Nutrition. 2018;

9. Sushil K, Mainalee M, Pandey N. Determinants and Prevalence of Stunting Among Rural Kavreli Preschool Children. EAST JOURNAL OF FAMILY MEDICINE. 2017;15(3).

10. JH R, A N, RO S. Low dietary diversity is a predictor of child stunting in rural Bangladesh. Eur $\mathrm{J}$ Chlinical Nutr. 2010;64:1393-1398.

11. M de O, F B. Childhood stunting: a global perspective. Matern Child Nutr. 2016;12-26.

12. Rahayu A, Khairiyati L. Risiko pendidikan ibu terhadap kejadian stunting pada anak 6-23 bulan. Panel Gizi Makan. 2014;

13. Huang W. Understanding the effects of education on health: evidence from China [Internet]. 2015. Available from: https://scholar.harvard.edu/ weihuang/publications/understanding-effects-educationhealth-evidence-china

14. Sanin KI, Islam MM, Mahfuz M, Ahmed AMS, Mondal D, Haque R. Micronutrient adequacy is poor, but not associated with stunting between 12-24 months of age: A cohort study findings from a slum area of Bangladesh. PLoS ONE. 2018;13(3):0195072.

15. Lisanu M, Andargie BG. Predictors of Stunting among School-Age Children in Northwestern Ethiopia. J Nutr Metab. 2018 Sep;20.

16. Ekawaty M, Kawengian SES, Kapantow NH. Hubungan antara pengetahuan ibu tentang gizi dengan status gizi anak umur 1-3 tahun di Desa Mopusi Kecamatan Lolayan Kabupaten Bolaang Mongondow Induk Sulawesi Utara. Jurnal e-Biomedik (eBM). 2015;3(2):609-14.

17. Aries M, Hardinsyah, Tuhiman H. Determinan gizi kurang dan stunting pada anak umur 0-36 bulan berdasarkan data program keluarga harapan (PKH) 2007. Jurnal Gizi dan Pangan. 2012;7(1):19-26.

18. Cruz LMG, Azpeitia GG, Súarez DR, Rodríguez AS, Ferrer JFL, Serra-Majem L. Factors Associated with Stunting among Children Aged 0 to 59 Months from the Central Region of Mozambique. Nutrients. 2017 May 12;9(5):491.

19. SILVA, Diana. Relationship between the mothers nutritional status with that of a child population from São Tomé Principe, ‘Africa’. Rev Bras Saude Mater Infant. 2017;17(2):2019-08-21], pp.327-335.

20. Rahmad AHAL, Miko A. Kajian stunting pada anak balita berdasarkan pola asuh dan pendapatan keluarga di Kota Banda Aceh. Jurnal Kesmas Indonesia. 2016;

21. Safitri CA, Nindya TS. Hubunganketahanan pangan dan penyakit diaredengan stunting pada balita 1348bulan di Kelurahan Manyar Sabrangan,Surabaya.J Amerta Nutr. 2017-1 p. 
22. Pipes LP. Nutrition in infancy and childhood. Missouri: Times Mirror/ Mosby College Publishing; 1985.

23. Kusumawati E, Rahardjo S, Sari HP. Model pengendalian faktor risiko stunting pada anak usia di bawah tiga tahun. Jurnal Kesehatan Masyarakat Nasional. 2015;9(3):249-56.

24. Aridiyah FO, Rohmawati N, Ririanty M. Faktor-faktor yang mempengaruhi kejadian stunting pada anak balita di wilayah pedesaan dan perkotaan. e-Jurnal Pustaka Kesehatan. 2015;

25. Dekker LH, Mora-Plazas M, Marín C, Baylin A, Eduardo. Stunting associated with poor socioeconomic and maternal nutrition status and respiratory morbidity in Colombian schoolchildren. Food and Nutrition Bulletin. 2010;31(2).

26. Prendergast AJ. Malnutrition and vaccination in developing countries. Philos Trans R Soc Lond B Biol Sci. 2015;

27. Beal T, Tumilowicz A, Sutrisna A, Izwardy D, Neufeld LM. A review of child stunting determinants in Indonesia. Matern Child Nutr. 2018(14).

28. Ponamon NS. Hubungan antara durasi dan frekuensi sakit balita dengan terjadinya stunting pada anak SD di Desa Kopandakan 1 Kecamatan Kotamobagu Selatan (skripsi). Fakultas Kesehatan Masyarakat Universitas Samratulangi; 2015.

29. Weisz A, Meuli G, Thakwalakwa C, Trehan I, Maleta K, Manary M. The Duration of Diarrhea and Fever is Associated with Growth Faltering in Rural Malawian Children Aged 6-18 Months. Nutrition Journal. 2011;

30. Efendhi A. Hubungan kejadian stunting dengan frekuensi penyakit ISPA dan diare pada balita usia 12-48 bulan di wilayah kerja Puskesmas Gilingan Surakarta (skripsi). [Surakarta]: Universitas Muhammadiyah; 2015.

31. Welasasih BD, Wirjatmadi RB. Beberapa faktor yang berhubungan dengan status gizi balita stunting. The Indonesian Journal of Public Health. 2012;8(3).

32. Danaei G, Andrews KG, Sudfeld CR. Risk Factors for Childhood Stunting in 137 Developing Countries: A Comparative Risk Assessment Analysis at Global, Regional, and Country Levels. PLoS Med. 2016 Nov;13(11).

33. Berendsen MLT, Smits J, Netea MG, van der Ven A. Non-specific Effects of Vaccines and Stunting: Timing May Be Essential. EBioMedicine. 2016;8.

34. Rahayu A, Yulidasari F, Putri AO, Rahman F. Riwayat berat badan lahir dengan kejadian stunting pada anak usia bawah dua tahun. Jurnal Kesehatan Masyarakat Nasional. 2015;

35. Apoina K, Suhartono S, HW B, Emman IM. Kejadian stunting dan kematangan usia tulang pada anak usia sekolah dasar di daerah pertanian Kabupaten Brebes. J Kesehat Masy. 2016;

36. Rosmalina Y, Luciasari E, Aditianti E, F. Upaya pencegahan dan penanggulangan batita stunting: systematic review. Jurnal Gizi Indonesia. 2018;

37. Vonaesch P, Tondeur L, Breurec S. Factors associated with stunting in healthy children aged 5 years and less living in Bangui (RCA). PLoS One. 2017;12(8).

38. Fikadu T, Assegid S, Dube L. Factors associated with stunting among children of age 24 to 59 months in Meskan district, Gurage Zone, South Ethiopia: a case-control study. BMC Public Health. 2014 Aug 14;7.

39. Vaozia S, Nuryanto. Faktor risiko kejadian stunting pada anak usia 1-3 tahun (studi di Desa Menduran Kecamatan Brati Kabupaten Grobogan). Journal of Nutrition College. 2016;

40. Hindrawati N, Rusdiarti. Gambaran riwayat pemberian ASI eksklusif dengan kejadian stunting pada anak usia 6-24 bulan di Desa Arjasa Kecamatan Arjasa Kabupaten Jember. JKAKJ. 2018;2(1). 
41. NorrisSA. Africa in Transition: Growth Trends in Children and Implications for Nutrition. Ann Nutr Metab. 2014;

42. Lestari E, Hasanah F, Nugroho N. Correlation between non-exclusive breastfeeding and low birth weight to stunting in children [Internet]. 2018. Available from: https://paediatricaindonesiana.org/index.php/paediatrica-indonesiana/article/view/1140

43. Bentian I, Mayulu N, Rattu AJM. Faktor risiko terjadinya stunting pada anak TK di wilayah kerja Puskesmas Siloam Tamako Kabupaten Kepulauan Sangihe Provinsi Sulawesi Utara. Jurnal Ilmu Kesehatan Masyarakat Unsrat. 2015;

44. Kementerian Kesehatan RI. Mengenal herd immunity dalam imunisasi [Internet]. 2018. Available from: http://www.depkes.go.id/ pdf.php?id=17042600003

45. Gaayeb L, Sarr JB, Cames C. Effects of malnutrition on children's immunity to bacterial antigens in Northern Senegal. Am J Trop Med Hyg. 2014;90(3).

46. Vonaesch P. Identifying the etiology and pathophysiology underlying stunting and environmental enteropathy: study protocol of the AFRIBIOTA project. BMC Pediatrics. 2018;18.

47. Damayanti RA, Muniroh L, Farapti. Perbedaan tingkat kecukupan zat gizi dan riwayat pemberian ASI eksklusif pada balita stunting dan non stunting. Media Gizi Indonesia. 2016;

48. Barilla Center for Food and Nutrition. Barilla Center for Food and Nutrition. Healthy growth and nutrition in children. Parma: Barilla Center for Food and Nutrition; 2009.

49. Saaka M, Galaa SZ. Relationships between Wasting and Stunting and Their Concurrent Occurrence in Ghanaian Preschool Children. J Nutr Metab. 2016;

50. Fatemeh E, Roshanak. Major Dietary Patterns in Relation to Stunting among Children. J HEALTH POPUL NUTR. 2013;31(2):202-10.

51. Schoenbuchner SM, Dolan C, Mwangome M, Hall A. Stephanie A Richard, Jonathan C Wells, Tanya Khara, Bakary Sonko, Andrew M Prentice, Sophie E Moore, The relationship between wasting and stunting: a retrospective cohort analysis of longitudinal data in Gambian children from 1976 to 2016. The American Journal of Clinical Nutrition, Volume. 2019 Aug;110(2):498-507. 